\title{
ESCHATOLOGIA, MESJANIZM I POLITYKA
}

udzie mają różne wyobrażenia Boga. Bóg Rousseau nie jest Bogiem Kierkegaarda. Od tego, jak wyobrażamy sobie Boga, zależy nie tylko nasza wiara, ale także nasze działanie w świecie. Bóg immanentny jest siłą aktywną, stale obecną we wszelkich przejawach życia, a zatem także życia politycznego. Wierząc w Boga immanentnego, mamy skłonność do ubóstwiania władzy politycznej, nadawania jej atrybutów boskich i jednocześnie oczekiwania, że dzięki nim władza będzie w stanie obronić nas przed siłami natury i mocami zła. Bóg immanentny to Bóg panteizmu.

Istnieje także Bóg teizmu - Bóg transcendentny, odległy od świata, który stworzył, lecz jednocześnie wciąż w niego ingerujący. Miłosierny, ale także okrutny. Człowiek otrzymał od niego świat we władanie, ale częścią tego świata jest zło i cierpienie, które wciąż mają przestrzegać ludzi przed grzechem pychy. Bóg transcendentny nie wtrąca się w nasz sposób rządzenia światem, ale oczekuje przestrzegania prawd objawionych, żąda posłuszeństwa i moralnej odpowiedzialności w każdej sferze życia, również w polityce.

Jest także trzeci obraz Boga - Bóg odwrócony od świata, nieobecny, milczący. Ten nieskończenie daleki Bóg to Bóg gnostyków. W gnostyckim obrazie świata naturalną potrzebą człowieka jest wycofanie się, ucieczka od teraźniejszości, która jest mrokiem. Jednak to, co dla jednych jest impulsem do ascezy i odrzucenia świata, $u$ innych może wywołać pragnienie zmieniania świata, aby przyspieszyć wyjście z tego mroku. Pokusa przyspieszenia apokalipsy może zrodzić także eschatologiczną wizje polityki. W tym kontekście gnostycyzm jawi sie jako teologiczne usprawiedliwienie rewolucji, w jego obrazie Boga kryje się niebezpieczny potencjał - zachęta do apokaliptycznego przetworzenia świata.
Dr Anna SIEWIERSKA-CHMAJ jest politologiem, wicedyrektorem Instytutu Badań nad Cywilizacjami w Wyższej Szkole Informatyki i Zarządzania w Rzeszowie. asiewierska@wsiz.rzeszow.pl 
Jądrem chrześcijaństwa jest wiara w Chrystusa - Boga, który stał się człowiekiem. Ta mesjanistyczna koncepcja wcielenia jest żywa we wszystkich nurtach chrześcijaństwa, choć w gnostycyzmie chyba najmocniej zaznaczona. W przeciwieństwie do judaizmu, chrześcijański Mesjasz wkroczył w obręb czasu, stał się częścią Historii. Opuszczając świat, Zbawiciel pozostawił człowieka samotnego, rozdartego niepokojem, z drugiej jednak strony dał ludziom wiarę w swoje ponowne przyjście i siłę, aby doczekać tego czasu. Odkupicielska obietnica, w określonych warunkach historycznych, może jednak przybrać kształt polityczny. Kościół od początku zdawał sobie sprawę z tego zagrożenia i starał się piętnować mesjanistyczne impulsy, które z zadziwiającą regularnością pojawiały się w Europie, zwłaszcza w okresach kryzysów spowodowanych przez klęski żywiołowe, choroby czy głód, jednak ich żywotność okazała się większa niż wysiłki Kościoła.

Hermann Cohen, który tak wiele pisał o idei mesjanistycznej w dziejach myśli europejskiej, nie wspominał o niebezpieczeństwie związanym z wyzwalaniem w ludziach tak potężnych namiętności. Pokusa, aby przyspieszyć przyjście Pana, zwłaszcza wtedy, gdy pojawia się prorok, święty mąż, człowiek z iskrą bożą, jest tak duża, że ludzie robią rzeczy, których nigdy nie zrobiliby, myśląc racjonalnie. Ale z drugiej strony, zbrodnie dokonywane w imię Stalina czy Hitlera były potworniejsze niż te dokonywane w imię Chrystusa, a przecież często towarzyszyła im chłodna kalkulacja. Czy jednak komunizm i nazizm zyskałyby taką rzesze wiernych, gotowych na wszystko wyznawców, gdyby ludzie ci nie zostali wcześniej intelektualnie przygotowani do przyjęcia eschatologicznej wizji świata i polityki? Stephen Marks, autor książki Dlaczego poszli za Hitlerem? Psychologia narodowego socjalizmu w Niemczech, dowodzi w jednym z rozdziałów, że specyficzny stan narodowosocjalistycznej świadomości można określić jako magiczny, w którym postać przywódcy obdarza się szczególnymi zdolnościami. W jednym z wywiadów, przeprowadzonych przez Marksa, Elvira Scheer wspomina: „Hitler, dobry bóg. Wie pan, on też był tak daleko. Właściwie wcale go tu nie było. Unosił się ponad wszystkimi, jak jakiś święty albo Jezus czy Maria"1. Nadawanie Hitlerowi cech nadprzyrodzonych, czy wprost mesjańskich, nie było ani sporadyczne, ani przypadkowe. Adolf Hitler budował swój wizerunek w oparciu o mitologię germańską, ale z czasem retoryka nazistowska nabrała także religijnego brzmienia - zaczęto roku budować mit mesjanistyczny, mit Zbawiciela. Führer o zabitych podczas puczu w 1923 roku mawiał "moi apostołowie”. Goebbels podsycał tendencje do utożsamiania Führera z Mesjaszem, przedstawiając go jako wodza wypełniającego misję, gotowego do wszelkich poświęceń, jako człowieka, który z miłości do swego narodu zrezygnował z małżeństwa i rodziny i wiódł przykładne, skromne i proste życie ${ }^{2}$. Rytuały inicjacyjne SS odbywały się przy ołtarzu z portretem Hitlera, katechizm Hitlerjugend zaczynał się od stów „Wierzę w Adolfa Hitlera”, a sprzedawane powszechnie, świecące w nocy, pocztówki z wizerunkiem Hitlera miały ponoć chronić dom podczas bombardowań sif alianckich! Laurence Rees cytuje modlitwę, którą z nakazu propagandy odmawiały dzieci w niemieckich przedszkolach: „Drogi Führerze, kochamy cię jak naszych ojców i matki. Należymy do nich tak samo, jak należymy do ciebie. Ogarnij nas swoją miłością i opieką, o Führerze!"3.

Książka Marksa nie daje jednoznacznej odpowiedzi na pytanie, dlaczego nazizm był możliwy właśnie w Niemczech, ale nie ulega wątpliwości, że nauka Thomasa Hobbesa, który przestrzegał przed przekraczaniem cienkiej linii oddzielającej biblijną retorykę ducho-

\section{- ....}

Stephen Marks, Dlaczego poszli za Hitlerem? Psychologia narodowego socjalizmu w Niemczech, Warszawa 2009, s. 36.

2 Rosa Sala Rose, Krytyczny słownik mitów i symboli nazizmu, Sic!, Warszawa 2006, s. 109.

3 Laurence Rees, Naziści. Ostrzeżenie historii, Prószyński i S-ka, Warszawa 2005, s. 14. 
wego zbawienia od mesjanistycznej wizji zbawienia politycznego, właśnie w ojczyźnie Hegla, Rosenzweiga, Gogartena, Bubera czy Otto została niemal zupełnie zapomniana. Niemiecka liberalna teologia polityczna przygotowała grunt pod przyjęcie biblijnego języka zbawienia, nawet jeśli językiem tym posługiwali się politycy. W ślad za wiarą, że przesłanie biblijne można gładko dostosować do nowoczesnego życia politycznego, podążała pokusa zrealizowania tegoż przesłania natychmiast, tu na ziemi, w imię uświęconego narodu i u boku nowego Mesjasza: „Mesjanistyczne oczekiwania w przewidywalny sposób pociągają za sobą pewną niecierpliwość, zwłaszcza w momentach historycznego kryzysu - pisze Mark Lilla. - Pobożne wycofanie się z historii i polityki może tym samym, w wyniku reakcji zwrotnej, przekształcić się w namiętną ucieczkę w niekontrolowane działanie - oraz zastąpienie wierności wobec prawdziwego Mesjasza kultem ziemskiego, politycznego bożka"4.

Przed niebezpieczeństwem łączenia idei Boga z jakąkolwiek ideologią polityczną przestrzegał po I wojnie światowej Karl Barth, którego w liberalnej teologii politycznej przeraziła łatwość, z jaką broniła ona militaryzmu niemieckiego. W Liście do Rzymian (1922) Barth piętnuje wiarę liberalnych teologów w możliwość służenia Bogu i polityce jednocześnie. Dla tego szwajcarskiego teologa polityka jest podejrzana, każda bowiem władza oparta jest na tyranii. Mimo wszystko jednak język, którym posługuje się Barth jest tak głęboko przesiąknięty eschatologiczną tradycją protestantyzmu, że w sposób niezamierzony wpisuje się ogólną retorykę tego okresu. Po dojściu Hitlera do władzy, grupa przywódców Kościołów protestanckich i teologów nazywających siebie Chrześcijanami Niemieckimi (Deutsche Christen) zaczęła głosić poparcie dla ideologii nazistowskiej, zwłaszcza jej elementów antysemickich, Hitlera wpisując w ideę mesjanistyczną: „Chrystus przyszedł do nas poprzez Adolfa Hitlera, [...] poprzez jego władzę, jego uczciwość, jego wiarę, jego realizm, odnalazł nas Zbawiciel"5. Reakcją Bartha i skupionych wokół niego teologów było ogłoszenie w 1934 roku Barmeńskiej Deklaracji Teologicznej, w której potępiono łączenie jakiejkolwiek ideologii z argumentacją natury religijnej. Tylko Jezus Chrystus „jest jedynym Stowem Boga. Tylko Jego powinniśmy słuchać, tylko Jemu powinniśmy ufać i być posłuszni zarówno w życiu, jak i wobec śmierci"6.

Idea mesjanistyczna jest niezwykle silna także w religii żydowskiej, choć inaczej niż w chrześcijaństwie, koncentruje się nie na indywidualnym losie jednostki, lecz przybiera postać zbiorową - eschatologiczne nadzieje judaizmu zawsze dotyczyły przede wszystkim narodu żydowskiego, ludu Izraela. Jednak w mesjanizmie żydowskim koniec czasu jest równoznaczny z końcem ludzkiej historii, dlatego eschatologia religijna rzadko stawała się eschatologią polityczną. Nawet po II wojnie światowej i Holokauście część ortodoksyjnych Żydów była przeciwna utworzeniu państwa Izrael, widząc w tym bezbożną realizację planu bożego przez ludzi.

Hegel dostrzegał w judaizmie religię, która zastygła w czasie, religię apolityczną - Bóg Starego Testamentu był niezmienny, a zatem i Jego lud nie mógł się zmieniać bez wyraźnej woli Jahwe. Jednak Hegel, w przeciwieństwie do Franza Rosenzweiga, nie dostrzegł, że to oczekiwanie na świetlaną przyszłość, pragnienie zmiany świata na lepsze, dawało impuls do tworzenia utopijnych teorii politycznych. Ernst Bloch, łącząc żydowski mesjanizm z dialektyką marksistowską, stworzył projekt takiej właśnie politycznej utopii, mo-

\section{$\cdots \cdots$}

Mark Lilla, Bezsilny Bóg. Religia, polityka i nowoczesny Zachód, Warszawa 2009, s. 284

Clifford Green (red.), Karl Barth: Theologian of freedom, Minneapolis 1981, s. 24 za: Mark Lilla, Bezsilny Bóg. Religia, polityka i nowoczesny Zachód, dz. cyt., s. 287.

6 Ku wspólnemu rozumieniu Kościoła: Międzynarodowy dialog reformowano-rzymskokatolicki - Druga faza: 1984-1990, Studia i Dokumenty Ekumeniczne, http://www.luteranie.pl/ekumenia/46/465.htm. 
tywowanej z punktu widzenia Biblii. Bloch był teologiem ateistycznym, urodzonym w zasymilowanej niemieckiej rodzinie żydowskiej, nie przeszkadzało mu to jednak dokonać zadziwiającej syntezy Starego i Nowego Testamentu, apokaliptycznych pism Thomasa Müntzera ${ }^{7}$, protestanckiego pastora, który w XVI wieku stanął na czele chiliastycznego powstania chłopskiego, zakończonego masakrą arystokracji niemieckiej, oraz Manifestu komunistycznego. Wszystko po to, aby znaleźć uzasadnienie dla rewolucji, nawet jeśli w jej imieniu popełnia się zbrodnie. Bloch przekonywał, że największym buntownikiem w dziejach był nie kto inny, jak Jezus Chrystus, a tradycja judeochrześcijańska pokazuje nam pewien polityczny projekt, który może zaistnieć, jeśli ludzie wezmą na siebie odpowiedzialność budowania Królestwa Bożego na ziemi. Dla Blocha takim ziemskim prorokiem wyzwolenia był Karol Marks ${ }^{8}$. Jak pisze Hannah Arendt, Marks i Engels wierzyli, że religie są ideologiami, ale nie uważali, że ideologie po prostu stają się religiami ${ }^{9}$, Bloch poszedł zatem dalej, niż wyobrażali sobie to twórcy marksizmu. Ernst Bloch przeżył II wojnę światową, miał okazję na własne oczy zobaczyć zbrodnie stalinizmu i nazizmu i przekonać się, jakie konsekwencje niesie wykorzystanie gnostyckich pojęć apokalipsy i zbawienia do usprawiedliwienia realizacji politycznego projektu.

Także w dziewiętnastowiecznej Polsce żywe były nadzieje na przyjście Mesjasza i podjęcie przez niego zadań natury politycznej. Historia Polski, zinterpretowana w sposób metafizyczny, dostarczała zarówno polskim filozofom jak i poetom argumentów na rzecz niezwykłej roli narodu polskiego w dziejach świata. Niemal wszyscy bez wyjątku inspirowali się filozofią Hegla, co nie przeszkadzało im w katolicyzmie i polskości widzieć przeznaczenie świata. Józef Maria Hoene-Wroński, Józef Gołuchowski, Bronisław Trentowski - „wszyscy byli heglistami co do formy i mesjanistami co do treści”10. Wroński, pozostający zresztą w permanentnym konflikcie z Mickiewiczem, zarzucit poecie przywłaszczenie pojęcia mesjanizmu dla określenia losów narodu polskiego. Tymczasem to właśnie Wrońskiemu można zarzucić koniunkturalne wykorzystanie romantycznej idei mesjanistycznej dla propagowania swojej filozofii absolutu, mesjanizm był bowiem w tym okresie tak powszechny, że wpisanie się w ten nurt dawało szansę na dotarcie do szerokich rzesz czytelników, zwłaszcza w kręgach francuskiej Polonii.

Duży wkład w propagowanie idei mesjanistycznej w Polsce miała filozofia Augusta Cieszkowskiego, który nie godząc się na osobowego Mesjasza, innego niż sam Chrystus, jednocześnie w Słowianach widział grupę szczególnie predestynowaną - przez swoją dzielność, unikanie ekstremizmów i umiłowanie wolności - do roli przewodników dla reszty ludzkości. „Cieszkowski nie przypisywał żadnemu narodowi misji soteriologicznej - twierdzi Andrzej Sepkowski w książce Utopie polskiego romantyzmu - i nie mógł tego czynić, eksponując w taki sposób rolę Chrystusa. To nie Mesjasz narodowy wprowadzi ludzkość w epokę trzecią, a ona sama osiągnie ją przez stawanie się bytem dla siebie"11. Cieszkowski inspirował wielu ówczesnych twórców, z Zygmuntem Krasińskim i Cyprianem Kamilem Norwidem na czele. Norman Davies twierdzi nawet, że Cieszkowski, próbując łączyć utopijną ideę „epoki Ducha Świętego" i wiarę w boską misję Kościoła katolickiego z celami politycznymi i społecznymi, był prekursorem marksizmu². Rzeczywiście, Karol Marks znał dzieła Cieszkowskiego, jednak w przeciwieństwie do Pierre'a Proudho-

Kwartalnik Diecezjalny „Ewangelik”, http://www.luteranie.pl/ewangelik/daty/Daty_2.html.

8 Vincent Geoghegen, Ernst Bloch, Routledge, New York 1996, s. 104-125.

9 Hannah Arendt, Salon berliński i inne eseje, Warszawa 2008, s. 186.

10 Władysław Tatarkiewicz, Historia filozofii, tom II, Warszawa 1978, s. 232

11 Andrzej Sepkowski, Utopie polskiego romantyzmu. Światopogląd a działanie, Piotrków Trybunalski 1997, s. 205.

12 Norman Davies, Boże igrzysko. Historia Polski, tom II, Kraków 1992, s. 64. 
na, uważanego za ojca ideologii anarchistycznej, nigdy nie przyznał się do inspiracji dziełami polskiego filozofa.

Nie mniejszy wpływ na polską ideę mesjanistyczną miał Andrzej Towiański, sam siebie określający jako proroka Sprawy Bożej. W przeciwieństwie do mesjanizmu niemieckiego, Towiański nawoływał do rewolucji chrześcijańskiej, która nawet w politycznym wrogu widzi bliźniego. Towianizm głosił potrzebę naśladowania Chrystusa, Polakom powierzając szczególne zadania, choć nie szczególne przymioty. Z tego też powodu, mimo że inspirował Adama Mickiewicza, Juliusza Słowackiego czy Seweryna Goszczyńskiego, czyli poetów wpisujących się w teorię, że Polska jest Chrystusem narodów, sam był posądzany o brak patriotyzmu. Idee mesjanistyczne często tworzą ideologiczne fundamenty nacjonalizmów, tymczasem mesjanizm Towiańskiego był od tego daleki. Towiański wierzył w posłannictwa różnych narodów i, obok Polaków, szczególną rolę do spełnienia przypisywał także Francuzom i Żydom - „starszym braciom” w wierze. Andrzej Zdziechowski, autor książek o mesjanizmie polskim, pragnąc wyjaśnić wątpliwości co do przesłania towianizmu, spotkał się z wieloma jego uczniami, m.in. z Karolem Baykowskim:

„Dwa uczucia - patrjotyzm i religja - staczały ze sobą zażartą walkę w duszy Baykowskiego: patrjotyzm usprawiedliwiał wszystkie drogi wiodące do wyzwolenia ojczyzny - spiskowania, kłamstwo, zdrade - religja zaś nakazywała przebaczać wrogom a nawet ich miłować. (...) Dopiero spotkanie Towiańskiego i żywe jego słowo wstrząsnęło nim do głębi sumienia i znalazł spokój i radość w nauce mistrza, podług której „tylko tym, którzy zbawiają duszę swoją przez bezwzględną miłość i ofiarę dla Boga, danym będzie przyczynić się do zbawienia ojczyzny, bo ojczyznę zbawimy nie my, ale Bóg przez nas, o ile czyści przed nim będziemy"13.

Baykowski z filozofii Towiańskiego wyciągnął wnioski na rzecz zaniechania walki w imię miłości bliźniego i podrzędności polityki w stosunku do religii, Mickiewicz wręcz przeciwnie - z każdym rokiem jego poglądy stawały się coraz bardziej radykalne.

ESCHATOLOGIA / REWOLUCJA

Walka z religią i Kościołem była jednym z priorytetowych założeń Rewolucji Francuskiej - nie dało się zniszczyć stanowego społeczeństwa ancien règime'u, bez zniszczenia duchowieństwa, tworzącego ważną część ówczesnej hierarchii społecznej. Ale wrogość rewolucyjnego reżimu w stosunku do religii, była porównywalna z wrogością Kościoła w stosunku do samej istoty rewolucji. Naiwnością byłoby sądzić, iż ta wzajemna niechęć spowodowana była jedynie czynnikami natury społeczno-politycznej. To prawda, że trzon elity rewolucyjnej stanowili ateiści, prawdą jest także oczywisty związek Kościoła katolickiego we Francji ze starym porządkiem i monarchią, nie tłumaczy to jednak do końca powodów tak głębokiej nienawiści. Aleksander Hall uważa Rewolucję Francuską za jedną z największych i najkrwawszych z francuskich wojen religijnych. Powołując się na François Fureta, wielkiego historyka Rewolucji Francuskiej, który jako jeden z pierwszych zauważył eschatologiczne motywy tej wrogości, pisze:

„Rewolucja niosła ze sobą obietnice zbawienia na ziemi, "ubóstwiając» wolność i równość, ale odrywając te pojęcia od uzasadnienia religijnego. Była to zasadnicza różnica pomiędzy Rewolucją Francuską i amerykańską. Ta druga zachowała harmonię między sferą polityczną

13 Andrzej Zdziechowski, Andrzej Towiański (1799-1878). Wykład wygłoszony dnia 9 grudnia 1910 roku, w: Polska filozofja narodowa, Kraków 1921, s. 149-150. 
i religijną. Radykalni rewolucjoniści francuscy widzieli w religii katolickiej konkurencję w dziele zbawiania człowieka. Chcieli przez Rewolucję i ubóstwienie jej zasad przynieść zbawienie Nowemu Człowiekowi tu, na ziemi"14.

Państwo rewolucyjne prowadziło dechrystianizację - kościoły zamykano i profanowano, księża trafiali na gilotynę, ale Maximilien Robespierre był przeciwnikiem ateizmu - pokusa wykorzystania religii w celach politycznych była zbyt duża, aby z niej zrezygnować. Robespierre zgodzitby się z Le Bonem, że tłum potrzebuje religii. Wydaje się zresztą, że, wbrew wszelkim działaniom radykalnych hebertystów, idea sakralizacji nowego porządku pojawiła się oddolnie i spontanicznie - niemal od początku zaczął się plenić kult rewolucyjnych męczenników, ludzie potrzebowali religijnego uprawomocnienia nowej władzy. W listopadzie 1793 roku paryską Notre Dame, podobnie jak wiele innych kościołów, zamieniono w Świątynię Rozumu, w której odbywały się świeckie rytuały, rok później Robespierre wprowadził deistyczny kult Istoty Najwyższej, który miał wypełnić metafizyczną pustkę po katolicyzmie i stworzyć zręby nowego republikańskiego katechizmu. Robespierre, wielki admirator Rousseau, podstawą nowej wiary uczynił jego poglądy na Naturę i kierującą wszystkim, Istotę Najwyższą. W mowie wygłoszonej w Konwencji w maju 1794 roku ostro zaatakował działania Jacques'a René Héberta i skupionego wokół niego antyteistycznego środowiska wrogiego wobec idei Boga i religii:
„Jakiż zysk widzisz w przekonywaniu człowieka, iż jakaś ślepa siła rządzi jego losem i uderza przypadkowo w zbrodnię lub cnotę? (...) Czyż idea jego nicości (Bóstwa) tchnie weń uczucia czystsze i wznioślejsze niż idea jego nieśmiertelności? Czyż tchnie weń więcej szacunku dla bliźnich i dla siebie samego, więcej oddania dla ojczyzny, więcej śmiałości do sprzeciwiania się tyranii, więcej wzgardy wobec śmierci lub wobec lubieżności? (...) Idea Najwyższej Istoty i nieśmiertelności duszy jest ustawicznym przywoływaniem sprawiedliwości; jest zatem spo- łeczna i republikańską"15.

Opowiadając się za wiarą, widział w niej podstawę moralności społeczeństwa, podkreślał jej wychowawczy charakter, jednocześnie jasno artykułując niechęć Republiki wobec kapłanów, uzurpujących sobie rolę pośredników między niebem a ziemią:

„Prawdziwym kapłanem Najwyższej Istoty jest Natura; jej świątynią świat, jej kultem cnota; jej świętami - radość wielkiego ludu"16.

Robespierre zdawał sobie sprawę z roli politycznych ceremoniałów, legitymizujących władzę w cyklicznych odstępach czasu, dlatego stworzył nie tylko nowy kult, ale także nowe, quasi-religijne, uroczystości. Zdawał sobie jednak także sprawę z ukrytej w religii obietnicy zmiany, dlatego nowe wyznanie było pozbawione eschatologicznego zabarwienia - Istota Najwyższa czuwała nad światem, ale czyniła to z dystansu, zadaniem człowieka było jedynie życie w zgodzie z nową republikańską moralnością, wyznaczoną przez wartości wolności, równości i braterstwa. Rewolucja już się dokonała, eschatologiczne namiętności, dla dobra stabilności państwa, należało teraz ugasić.

Wydaje się, że niezwykły związek połączył religię i politykę także w rewolucyjnej Rosji. Nie chodzi bynajmniej o szeroko opisywaną kwestię podobieństwa marksizmu do mitologii mesjanistycznej, w którym zbiorowym Mesjaszem jest cała klasa robotnicza, ale o mało znaną sektę staroobrzędowców, która zaangażowała się w pomoc bolszewikom, widząc w rewolucji realizację eschatologicznych zapowiedzi, od początku obecnych w tej religii. Staroobrzędowcy, lepiej znani jako raskolnicy, to odłam prawosławia powsta-

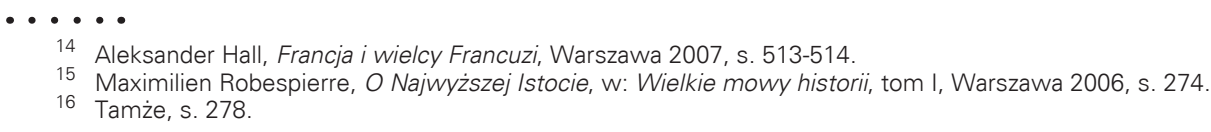


ty w Rosji w wyniku sprzeciwu wobec reform patriarchy Nikona w 1652 roku. Staroobrzędowcy uznali wprowadzoną wtedy zmianę rytów za herezję, zwiastującą koniec świata. Po uwięzieniu i spaleniu na stosie przywódcy duchowego, Awwakuma Pietrowicza, część raskolników uznała, że jedyną drogą do Boga pozostaje samospalenie. Całą Europą wstrząsały co pewien czas informacje o zbiorowych samobójstwach, których dokonywano, zamykając się całymi rodzinami w cerkwiach i podkładając pod nie ogień. Ruch raskolników, obłożony klątwą przez sobór w 1666 roku, został poddany niewyobrażalnym represjom, większość hierarchii duchownej została wtedy zamordowana z rozkazu cara Aleksego I. Dla staroobrzędowców każdy car był Antychrystem. Pomimo tego, że w 1905 roku Mikołaj II ogłosił ukaz tolerancyjny, przyznający staroobrzędowcom wolność religijną, raskolnicy $w$ dużej części opowiedzieli się po stronie rewolucji, ona także bowiem była przeciwko carowi i popierającej go cerkwi prawosławnej.

Przede wszystkim jednak zaważyła chyba wspólna wizja świata. Eschatologiczne napięcie, towarzyszące prawosławnym sektom oraz powszechny strach chłopów rosyjskich przed końcem świata, który miałby nastąpić wraz z nastaniem nowego, dwudziestego wieku, okazały się żyzną ziemią dla ruchów rewolucyjnych. Kiedy Siergiej Nieczajew, autor słynnego Katechizmu rewolucjonisty, często mylnie przypisywanego Michaiłowi Bakuninowi, sformułował zasadę, w myśl której:

„Nie uznajemy żadnej innej działalności poza eksterminacją, chociaż przyznajemy, że formy tej działalności mogą być różne - trucizna, nóż, sznur itd. W tej walce rewolucja uświęca wszystko",

wielu rewolucjonistów przeraziło jej amoralne przesłanie. Nawet Bakuninem, przyjacielem i protektorem Nieczajewa, wstrząsnęła ta sakralizacja przemocy, w liście do przyjaciela nazwał sformułowane przez niego zasady „,jezuickim systemem” i odrzucił Katechizm" Co ciekawe, eschatologiczny język Nieczajewa, i jemu podobnych skrajnych rewolucjonistów, był bardzo zbliżony do języka sekt prawosławnych. Kiedy Bakunin w 1869 roku wezwał rewolucjonistów rosyjskich do „pójścia w lud”, kazał im poznać język chłopów i robotników rosyjskich, odrzucić intelektualną skorupę, która była barierą w dotarciu z ideą rewolucyjną do prostych ludzi:

„Zwróćcie uwage na naukę, w której imieniu ludzie próbują was ujarzmić i pozbawić siły. Nauka tego typu musi zniknąć wraz ze światem, którego jest częścią"18.

Odwoływanie się do prostej, ludowej religijności było narzędziem, które pozwalało rewolucjonistom wpisywać idee rewolucyjne w powszechne wśród chłopów oczekiwanie na przyjście Mesjasza i koniec świata. Jedna z rosyjskich sekt prawosławnych, chłyści, nazywająca siebie ludźmi bożymi, bezpośrednio zaangażowała się po stronie rewolucjonistów, zajmując się kolportażem bolszewickich ulotek. Prawdopodobnie chłystą był m.in. Grigorij Jefimowicz Rasputin, nazywany czasami niekoronowanym carem Rosji, tak skutecznie bowiem manipulował carem Mikołajem II, zwiększając i tak ogromną już niechęć Rosjan do rodziny carskiej i władzy w ogóle. Czy rewolucja bolszewicka potoczyłaby się inaczej, gdyby ministrem spraw wewnętrznych nie został, dzięki protekcji Rasputina, Aleksander Protopopow - człowiek zupełnie nie zorientowany w sprawach resortu? Trudno dzisiaj odpowiedzieć na to pytanie, faktem jest jednak, że został nominowany na to stanowisko na przełomie 1916/17 roku, a więc w przededniu rewolucji. O szokującej ignorancji Protopopowa świadczy chociażby jego wypowiedź ze stycznia 1917 roku. Podczas

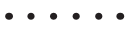

17 Paul Avrich, Anarchist portraits, fragm. niepublikowanej książki w tłumaczeniu Iwo Czyża za: http://bractwotrojka.republika.pl/bakunin/arty_avrich2.htm.

18 Tamże. 
gdy Rosję ogarnęła fala brutalnie tłumionych przez władze strajków, Protopopow oświadczył, że rewolucja w Rosji wybuchnie prawdopodobnie za 50 lat. Jak bardzo się mylit, pokazały wydarzenia kolejnych miesięcy. Carat upadtby prawdopodobnie i bez manipulacji Rasputina, jednak pozostanie tajemnicą, jak dalece jego działalność na dworze była związana z sektą chłystów i jej, uwarunkowaną eschatologicznie, sympatią dla rewolucji bolszewickiej.

\section{PAŃSTWO, NARÓD, RELIGIA}

Max Weber w książce Polityka jako zawód i powołanie dowodzi, że protestantyzm legitymizował państwo,

„a prawomocne państwo autorytarne w szczególności, widząc w nim urządzenie boskie. Luter zdejmował z jednostki etyczną odpowiedzialność za wojnę i przerzucał ją na zwierzchność. Posłuszeństwo wobec niej w innych sprawach niż sprawy wiary nigdy nie mogło być traktowane jako wina"19.

Weber napisał te słowa nieświadom hekatomby II wojny światowej, zmarł w 1920 roku, ale wydaje się, że trafił w sedno - ubóstwienie państwa, które nastąpiło za sprawą protestantyzmu, rzeczywiście zdejmowało z obywateli odpowiedzialność za działania państwa. Może właśnie dlatego, jak sądzi Hannah Arendt, nazizm był możliwy właśnie w Niemczech. Autorka Korzeni totalitaryzmu źródło zła dostrzega jednak nie w deifikacji państwa, a w utożsamieniu narodu i państwa. W polemicznym eseju Naród Arendt twierdzi:

„Nacjonalizm oznacza w zasadzie podbój państwa przez naród. (...) Podbój państwa przez naród rozpoczął się od ogłoszenia suwerenności narodu. Był to pierwszy krok przekształcający państwo w narzędzie narodu, który ostatecznie doprowadził do tych totalitarnych form nacjonalizmu, w których wszystkie prawa i wszystkie instytucje prawne państwa jako takie interpretuje się jako środki służące dobrobytowi narodu. (...) To właśnie naród uzurpował sobie tradycyjne miejsce Boga i religii" 20.

Związek religii i narodu nie był chyba nigdzie tak silny, jak w Niemczech, nie tylko za sprawą protestantyzmu, ale także filozofii Hegla, która odcisnęła piętno na większości myślicieli dziewiętnastowiecznych. Hegel przypisywał religii moc tworzenia narodu, budowania fundamentów etyczności państwa. W Wykładach z filozofii religii dowodzit, że wierzenia danego narodu pozostają z nim w pierwotnej jedności, odsłaniają głębszą prawdę o społeczeństwie jako ogóle. Wielu filozofów przed Heglem twierdziło podobnie, jednak tylko Hegel pisze o tym z taką aprobatą. Konflikty religijne wynikające z tak ścisłych powiązań religii, państwa i narodu są dla Hegla jedynie etapem rozwoju społeczeństw, częścią historii, lecz nie oczywistym skutkiem istnienia sakralnego węzła. Dla Hegla państwo opiera się na religii, a Bóg istnieje jako społeczność. Ten sposób myślenia przejął od Hegla Friedrich Gogarten, pisząc książkę Religia i narodowość, w której dowodzit, że Bóg, objawiając się ludziom, czyni to poprzez naród:

„Naród, Volk, i wszystko, co się z nim wiąże, w tym państwo, są całkowicie przesycone myślami i uczuciami religijnymi i są dla nas nosicielami nie tylko ziemskiego, ale także wiecznego życia"21.

19 Max Weber, Polityka jako zawód i powołanie, Kraków-Warszawa 1998, s. 105-106.

20 Hannah Arendt, Salon berliński i inne eseje, Warszawa 2008, s. 200.

21 Friedrich Gogarten, Religion und Volkstum, Jena 1915, tom I, s. 29 za: Mark Lilla, Bezsilny Bóg. Religia, polityka i nowoczesny Zachód, dz. cyt., s. 290. 
Dla Gogartena specjalna rola przypadała Niemcom, ich bowiem historia przypominała mu boskie objawienie, bardziej nawet niż historia Żydów. Wszystko zatem, co osłabiato naród, osłabiało jednocześnie religię, a zatem było złe, także liberalny protestantyzm, sprzyjający nowoczesności i indywidualizmowi. Gogarten szczególnie ostro atakował indywidualizm, rozluźniający tradycyjne więzi społeczne i rozmywający poczucie tożsamości narodowej - jego argumenty nadal zresztą przytaczają najróżniejsi fundamentaliści - protestanccy w Stanach Zjednoczonych czy katoliccy, skupieni w środowisku Radia Maryja w Polsce.

Friedrich Gogarten był tak konsekwentny w swoich poglądach, że nie tylko nie złagodził swojego stanowiska po 1933 roku, chociażby za namową Karla Bartha, swojego bliskiego przyjaciela, ale wręcz zradykalizowat je w polemicznym artykule Jedność Ewangelii i narodowości?, w którym podkreślił swoje poparcie dla nazistowskiego państwa totalnego. Dla Gogartena wszystko było lepsze niż chaos Republiki Weimarskiej, a nazistowski program, obiecujący powrót do totalnego charakteru wszelkiej władzy, boskiej i narodowej, gwarantował wielkość protestantyzmu i wielkość niemieckiego narodu. Gogartenowi bardziej chodziło o Boga niż o naród, ale jego głęboko eschatologiczny język, przejęty zresztą prawdopodobnie od Bartha, dostarczał argumentów nazistowskiej propagandzie. Niemiecka koncepcja narodu zakładała, że jest on zamknięty do wspólnoty krwi, ograniczony wspólną tradycją, wspólną historią i wspólną religią. Pisma Gogartena wpisywały się idealnie w niemiecki nacjonalizm, dając mu religijne uzasadnienie - w tym kontekście walka o sprawę narodową stawała się także walką o Boga i religię. Naród krwi z założenia niemal jest narodem walczącym, jego agresja projektowana jest na zewnątrz, przeciwko wszystkiemu, co obce. Religia staje się dodatkowym narzędziem identyfikacji i wzmacniania tożsamości obywatela.

Mikołaj Bierdiajew, wybitny rosyjski filozof, obserwując dwie wojny światowe i dwuznaczną rolę Kościoła, zwłaszcza w Niemczech, uważał, że bez protestanckiego partykularyzmu nie byłoby europejskiego nacjonalizmu. Bierdiajew wcześniej nawet niż Hannah Arendt zauważył niebezpieczeństwo deifikacji narodu i łączenia go z ideą Boga:

„Niemcy zaczęli wierzyć w Boga niemieckiego, ale Bóg niemiecki nie jest chrześcijański, to bóg tak pogański jak bóg rosyjski"22.

W młodości socjalista, w latach 30. stał się osobą głęboko wierzącą, nie przeszkadzało mu to jednak krytykować Cerkwi prawosławnej i jej związków z nacjonalizmem rosyjskim, podobnie jak protestantyzmu, za jego integralny niemal związek z nacjonalizmem niemieckim. Bierdiajew, podobnie jak Weber uważał, że protestantyzm legitymizował uległość wobec władzy państwowej, a tym samym zdejmował z wiernych odpowiedzialność za czyny dokonane w imię narodu i państwa.

Włodzimierz Bernacki w artykule Reformacja - u źródeł nacjonalizmu, podkreślając wpływ protestantyzmu na narodziny ideologii nacjonalistycznej, zauważa jednocześnie konieczność dokonania odróżnienia wpływu nurtu kalwińskiego od znaczenia, w tym kontekście, ruchu luterańskiego. Bernacki pisze:

"Jak się wydaje, luteranizm i kalwinizm odegrały istotną rolę w ukształtowaniu się w wiekach późniejszych dwóch zasadniczych modeli nacjonalizmu: nacjonalizmu obiektywno-politycznego i subiektywno-politycznego. Ten pierwszy, wyrosły na gruncie luterańskim, silnie odwoływat się do tradycji historycznej i traktował naród jako byt realnie istniejący. Ten drugi, poszukujący źródeł narodu w umowie społecznej, traktował naród w kategoriach przede wszystkim

22 Mikołaj Bierdiajew, Nowe średniowiecze, Komorów 1997, s. 121. 
politycznych, otwierając tym samym możliwość przystąpienia osób z zewnątrz. Pierwszy model rozwiną się w Europie Środkowej i Wschodniej, drugi właściwy jest dla społeczności anglosaskich (W. Brytania i USA)"23.

Od XIX wieku w Europie dominowało przekonanie, że najważniejszym źródłem autoidentyfikacji człowieka jest jego poczucie przynależności do określonej wspólnoty narodowej. Wydaje się, że jednak, że czym bardziej podkreślano, iż fundamentem tożsamości jest nie religia, lecz naród, tym więcej cech dotychczas zarezerwowanych dla religii przypisywano narodowi. Suwerenny naród miał niemal mistyczne znaczenie - nie był już tylko zbiorem jednostek połączonych wspólnym pochodzeniem czy kultem przodków, ale osobnym bytem, który miał swoje przeznaczenie, swoją wizję świata i prawo, żeby je realizować. Chociaż starotestamentowe pojęcie narodu wybranego dotyczyło Żydów, przekonanie, że Bóg ma swój lud wybrany i jest to właśnie nasz lud, było powszechne w wielu wspólnotach. Chrześcijaństwo przejęło ideę uświęcenia narodu przez jego religię, naród zyskał pierwiastek sacrum, nawet w państwach odcinających się od religii, jak Francja po Rewolucji.

Sakralizacja narodu dawała politykom niezwykłą władzę - pozwalała korzystać z niewyczerpanego zasobu biblijnych archetypów, metafor i symboliki. Uświęcony naród zyskiwał jednak także prawo do samostanowienia, do buntu wobec władzy, która nie posiadała już przecież boskiego namaszczenia, ponieważ religia legitymizowała teraz naród, nie zaś jego władcę. Władza traci mandat narodu, jeśli nie potrafi sprostać zbiorowym pragnieniom, ale z drugiej strony władza zyskuje nieograniczone niemal możliwości, jeśli staje się ucieleśnieniem mistycznej siły narodu.

W Mein Kampf Adolf Hitler wielokrotnie podkreśla, że Bóg przeznaczył specjalne zadanie dla narodu niemieckiego, a jest nim „rozrost naszej rasy i naszego narodu; dbałość o nasze dzieci i o zachowanie czystości krwi; wolność i niezależność ojczyzny"24. Sam postrzega siebie jako mesjasza, który został powołany przez Boga, aby zrealizować to zadanie - jako Führer ma mandat tak długo, jak długo będzie wypełniał swoją misję. Dla Hitlera Bóg jest tożsamy z naturą, nawet jeśli więc mówi językiem biblijnym, nawet jeśli bezpośrednio odnosi się do religii chrześcijańskiej, to traktuje ją instrumentalnie, jego wizja Boga i świata jest wizją neopogańską. Dla ideologów nazistowskich chrześcijaństwo było instrumentem kreowania wizerunku - instrumentem skutecznym, ponieważ stosowanym wobec narodu wyrosłego na fundamencie tej właśnie religii. Ale chrześcijański uniwersalizm, głoszący równość i braterstwo wszystkich ludzi i przedkładający je ponad sprawy narodowe, był sprzeczny z politycznym interesem Niemiec, a przede wszystkim sprzeczny z nazistowską wizją świata.

Bogumił Grott wyróżnił trzy różne typy relacji między religią a nacjonalizmem - koncepcje budowane w oparciu o zlaicyzowaną myśl europejską, często sprzeczne z założeniami chrześcijaństwa, lecz nie zwalczające ani Kościołów, ani religii - reprezentuje je m.in. Organizacja Ukraińskich Nacjonalistów. Ruchy neopogańskie, demonstrujące wrogość do chrześcijaństwa i postulujące podporządkowanie interesu Kościołów interesowi narodu - tu klasyfikuje się m.in. RUNWIRA, ukraiński neopogański ruch nacjonalistyczny, założony przez Lwa Syłenko, zarzucający prawosławiu przedkładanie interesów Moskwy nad interesy narodowe Ukrainy. Typ trzeci to nacjonalizm chrześcijański, deklarujący podporządkowanie ideologii narodowej zasadom etyki chrześcijańskiej - tu Grott zalicza m.in. polski ruch narodowy z ideologią Narodowej Demokracji, jako egzemplifikacją. Au-

\section{- ....}

23 Włodzimierz Bernacki, Reformacja - u źródet nacjonalizmu, w: Religia i polityka, B. Grott (red.), Kraków 2000, s. $14-15$.

24 Rosa Sala Rose, dz. cyt., s. 55. 
tor Nacjonalizmu chrześcijańskiego zauważa jednak, że do końca XIX wieku polski ruch narodowy nie był ściśle powiązany z religią, a wręcz charakteryzował się sporym indyferentyzmem religijnym, przy jednoczesnym szacunku dla Kościoła ${ }^{25}$. W klasyfikacji Grotta nacjonalizm niemiecki zalicza się do typu drugiego, neopogańskiego, nie oznacza to jednak, że propaganda nazistowska zrezygnowała z wykorzystywania elementów bogatej symboliki chrześcijańskiej. Ideowo i aksjologicznie czerpiąc z mitologii germańskiej, Hitler wykorzystywał chrześcijańskie kostiumy, aby wystawiać spektakle neopogańskie w treści. Chrześcijańska wizja świata nie daje się pogodzić z wizją pogańską, ale jeśli udaje się ukryć te fundamentalne sprzeczności, zyskujemy narzędzie podwójnie skuteczne.

W tym samym okresie, w którym nacjonalizm niemiecki plenił się na eschatologicznym podłożu protestantyzmu, czerpiąc siłę z pogańskich korzeni mitologii germańskiej, w Polsce trwała dyskusja nad nowoczesną koncepcją narodu. Antagonistów, czy to powołujących się na tradycję oświeceniową i pozytywistyczną oraz na laickość państwa, czy też na chrześcijańskie korzenie Europy i rolę Kościoła katolickiego w Polsce, łączyła jednak ogólna koncepcja narodu, postrzeganego nie jako wspólnota krwi, lecz jako zbiorowość połączona wspólnym szacunkiem dla określonych wartości kulturowych. Joanna Kurczewska dowodzi, że na polską koncepcję narodu, prócz szczególnych dla Polski zdarzeń historycznych, wpływ miała także tradycja romantyczna:

„Romantyczna zasada niesprzeczności między narodem a Uniwersum, przekonanie, że śmierć narodu umniejsza, zubaża całą ludzkość, przetrwała w socjologii narodu Ossowskiego i w Modern Nationalities Znanieckiego. W jakiś sposób ograniczała również biologizm i kult siły w polskich doktrynach egoizmu narodowego" 26 .

W ten sposób, pod wpływem polskiego romantyzmu, kategoria narodu stała się kategorią mistyczną i występowała jako równoprawna, obok innych koncepcji socjologicznych.

ESCHATOLOGY, MESSIANISM AND POLITICS

Sum mary

The article presents the issues of strong relations between various conceptions of God and their consequences - adopting a concrete vision of political life, nation, and state. The author shows relations between religion and politics in the context of political eschatology and political messianism, pointing to the examples of the French Revolution, nineteenth-century Polish messianism, revolutionary Russia, or Nazi Germany. Quoting various examples, the author poses the thesis that the vision of God and the place of religion in a given society strongly influence the political sphere, the perception of the state's role and the definition of a nation.

Keywords: eschatology, messianism, politics, religion, nation

25 Bogumił Grott, Model idealny „nacjonalizmu chrześcijańskiego” według ojca Józefa Marii Bocheńskiego na tle poglądów pokrewnych, w: Religia i polityka, dz. cyt., s. 103-104.

26 Joanna Kurczewska, Naród w socjologii polskiej, w: Dusza społeczeństwa. Naród w polskiej myśli socjologicznej, Warszawa 2002, s. 10. 